\title{
Report of rare case of intense parasitism by 34 specimens of Dioctophyme renale in a dog
}

\author{
Relato de caso raro de parasitismo intenso por 34 exemplares de \\ Dioctophyme renale em um cão
}

\begin{abstract}
Pâmela Caye ${ }^{\text {* }}$ (1D; Eduardo Santiago Ventura de Aguiar²; Joseana de Lima Andrades; Katiellen Ribeiro das Neves'; Mariana Cristina Hoeppner Rondelli2; Fabrício de Vargas Arigony Braga²; Fabiane Borelli Grecco3; júlia Ferrugem Kaiser; Josaine Cristina da Silva Rappeti²

${ }^{1}$ Hospital de Clínicas Veterinárias, Faculdade de Veterinária, Universidade Federal de Pelotas - UFPel, Pelotas, RS, Brasil 2Departamento de Clínicas Veterinárias, Faculdade de Veterinária, Universidade Federal de Pelotas - UFPel, Pelotas, RS, Brasil ${ }^{3}$ Departamento de Patologia Animal, Faculdade de Veterinária, Universidade Federal de Pelotas - UFPel, Pelotas, RS, Brasil ${ }^{4}$ Diagnóstico por Imagem - Stella Rausch, Pelotas, RS, Brasil
\end{abstract}

How to cite: Caye P, Aguiar ESV, Andrades JL, Neves KR, Rondelli MCH, Braga FVA, et al. Report of rare case of intense parasitism by 34 specimens of Dioctophyme renale in a dog. Braz J Vet Parasitol 2020; 29(4): e011820. https://doi.org/10.1590/S1984-29612020080

\begin{abstract}
Dioctophymosis is caused by Dioctophyme renale, a nematode that usually affects the right kidney of carnivores. The aim of this study was to report on a case of a dog with progressive weight loss and swollen abdomen that was diagnosed as presenting dioctophymosis. The patient underwent surgical treatment through which 34 nematodes were found, of which 18 were female and 16 were male, with a maximum length of 74 centimeters. The parasites were free in the abdominal cavity and inside the right kidney, and had caused peritonitis, free fluid, severe adherences between the abdominal organs and renal perforation. Parasitic diseases with a high number of specimens of this species are uncommon in dogs. The disease progresses with an inflammatory reaction and consequent formation of adherences and granulomatous tissue. This surrounds the eggs that were eliminated in the abdominal cavity by the free parasites. This disease occurs frequently in the city of Pelotas, Rio Grande do Sul, Brazil, where the patient of this report was living. To the best of authors' knowledge, this is the case with the largest number of specimens of $D$. renale removed from a single dog in vivo.
\end{abstract}

Keywords: Dioctophymosis, helminth, kidney.

\section{Resumo}

A dioctofimose é causada por Dioctophyme renale, um nematódeo que geralmente afeta o rim direito de carnívoros. Este trabalho objetivou relatar o caso de um cão, com perda de peso progressiva e abaulamento abdominal, diagnosticado com dioctofimose. $\mathrm{O}$ paciente foi submetido a tratamento cirúrgico, o que permitiu o achado de 34 nematódeos, sendo 18 fêmeas e 16 machos, com tamanho máximo de 74 centímetros. Os parasitos encontravam-se livres na cavidade abdominal e no interior do rim direito, causando peritonite, formação de líquido livre, intensas aderências entre os órgãos abdominais e uma perfuração renal. Parasitoses com alto número de exemplares dessa espécie são incomuns em cães. Cursam com reação inflamatória, com consequente formação de aderências e tecido granulomatoso, envolvendo os ovos eliminados na cavidade abdominal pelos parasitos livres. A doença é frequente na cidade de Pelotas, Rio Grande do Sul, Brasil, área de origem da paciente afetada. De acordo com a pesquisa realizada, acredita-se que esse é o caso com o maior número de exemplares de $D$. renale removidos de um cão in vivo.

Palavras-chave: Dioctofimose, helmintos, rim. 
Dioctophyme renale (Goeze, 1782) is a nematode that causes dioctophymosis, a parasitic disease of chronic nature. This parasitosis develops through an indirect biological cycle and affects wild animals, domestic animals and humans. Infection occurs through ingestion of infective larvae that are present in the intermediate host (Lumbriculus variegatus) or in paratenic hosts (fishes and frogs) (Mace \& Anderson, 1975). The right kidney is the organ mostly affected by this disease, which leads to destruction of the renal parenchyma, with consequent loss of organ function (Measures, 2001; Pedrassani \& Nascimento, 2015).

The erratic cycle of $D$. renale may facilitate the finding of parasites in other anatomic regions. Case reports describe the finding of the nematode free in the abdominal cavity (Paras et al., 2018; Butti et al., 2020), left kidney (Perera et al., 2017b), mammary gland (Paras et al., 2018), prostate (Butti et al., 2020) and abdominal musculature (Caye et al., 2018)

The clinical signs presented by animals affected by this parasitic disease are variable, and clinical signs include apathy, progressive weight loss, hematuria (Radman et al., 2017), ascites and abdominal pain (Measures, 2001). However, clinical signs are often unapparent (Mesquita et al., 2014; Pedrassani et al., 2017). Drugs are ineffective for controlling the disease, and it can only be treated surgically, through nephrectomy of the parasitized kidney or direct removal of the parasite (Pedrassani \& Nascimento, 2015). The aim of this study was to describe a case of a dog with high parasitic load of helminths of the species $D$. renale.

A five-year-old female dog of the Bull Terrier breed was attended at the Veterinary Hospital of the Federal University of Pelotas, because it presented a swollen abdomen that had been evolving for 20 days and progressive weight loss. The patient was dehydrated, with pale-pink mucosae, and was tachypneic and tachycardic. From abdominal ultrasonography, a diagnosis of renal dioctophymosis with dissemination in the abdominal cavity was made. In addition, the patient presented peritonitis, edematous mesentery and a moderate quantity of free fluid.

Laboratory analyses revealed anemia (Hb 8.8 g.dL-1; Hct 26.5\%), hypoalbuminemia (2.29 g.dL-1), hematuria, leukocyturia and presence of $D$. renale eggs in the urine. The serum biochemical tests showed that the levels

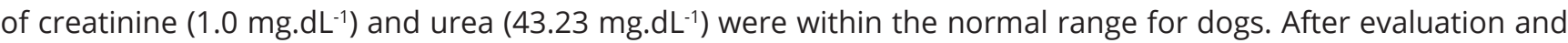
stabilization, the patient was sent for the surgical procedure of exploratory laparotomy and right nephrotomy for the treatment of the disease.

Several specimens of free $D$. renale were removed from the abdominal cavity and from inside the right kidney, which presented perforation of its capsule, thus enabling translocation of the parasites. Parasites were found in the upper right abdominal quadrant, in the right lateral and hypochondriac regions, in the kidney and liver and in body fluids containing blood, in moderate quantity. The omentum was reactive, with proliferative areas adhering to the liver, stomach, small and large intestines, pancreas, spleen, urinary bladder and internal abdominal wall.

In total, 34 parasite specimens were removed, among which 27 were free in the abdominal cavity and seven were inside the right kidney (Figure 1). The parasites were identified according to their sizes, coloration, anterior extremity with hexagonal mouth without lips and posterior extremity with a copulatory bursa in the males and

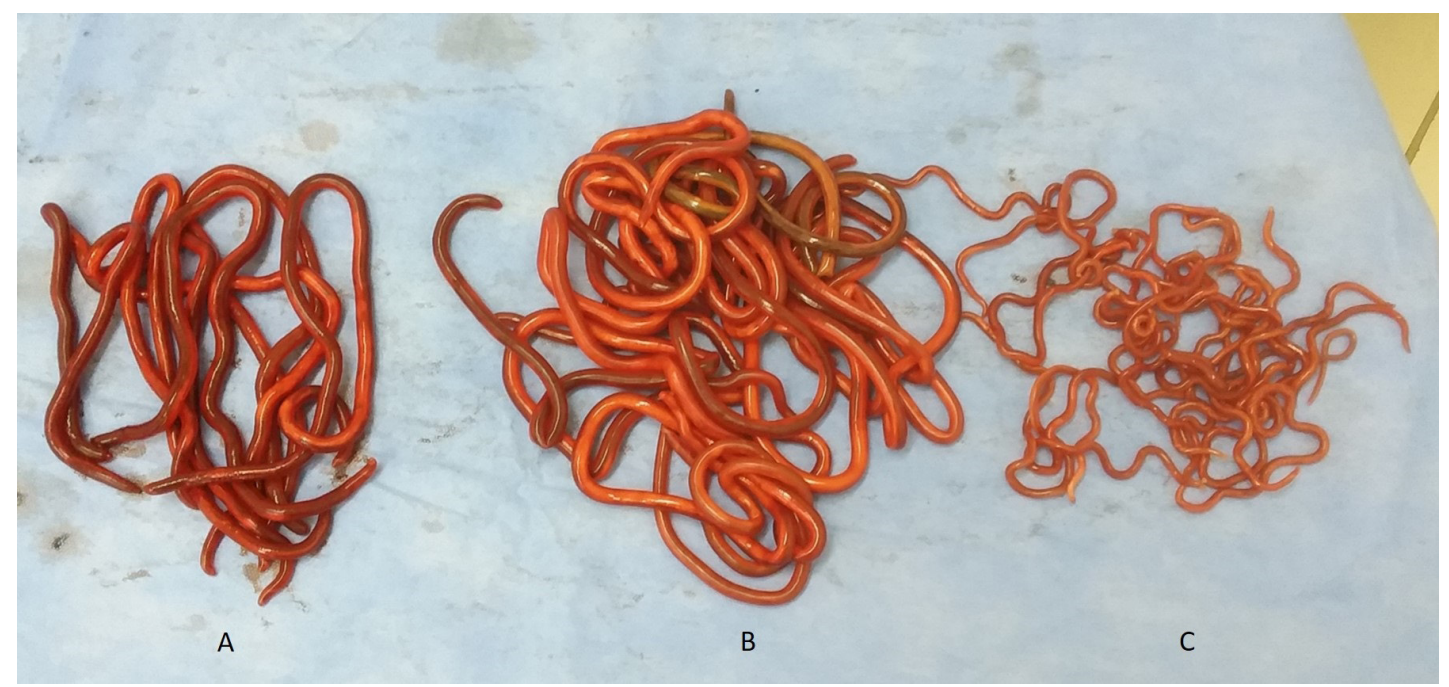

Figure 1. Thirty-four nematodes of the species Dioctophyme renale removed from a single dog. (A) Females (seven) found inside the right kidney; (B) Females (11) removed from the abdominal cavity; (C) Males (16) removed from the abdominal cavity. 
an obtuse tail in the females (Pedrassani \& Nascimento, 2015; Butti et al., 2018). All of them presented normal coloration and presence of intense motility. There were 11 females and 16 males in the abdominal cavity (Figure 2), and all the seven parasites in the right kidney were female. While the free-living females in the abdominal cavity had a mean length of $56.45 \mathrm{~cm}$ (range from 15 to $74 \mathrm{~cm}$ ), those females in the kidney had a mean length of $42.57 \mathrm{~cm}$ (range from 39 to $45 \mathrm{~cm}$ ). The males had a mean length of $24.93 \mathrm{~cm}$, with a range from 21 to $30 \mathrm{~cm}$.
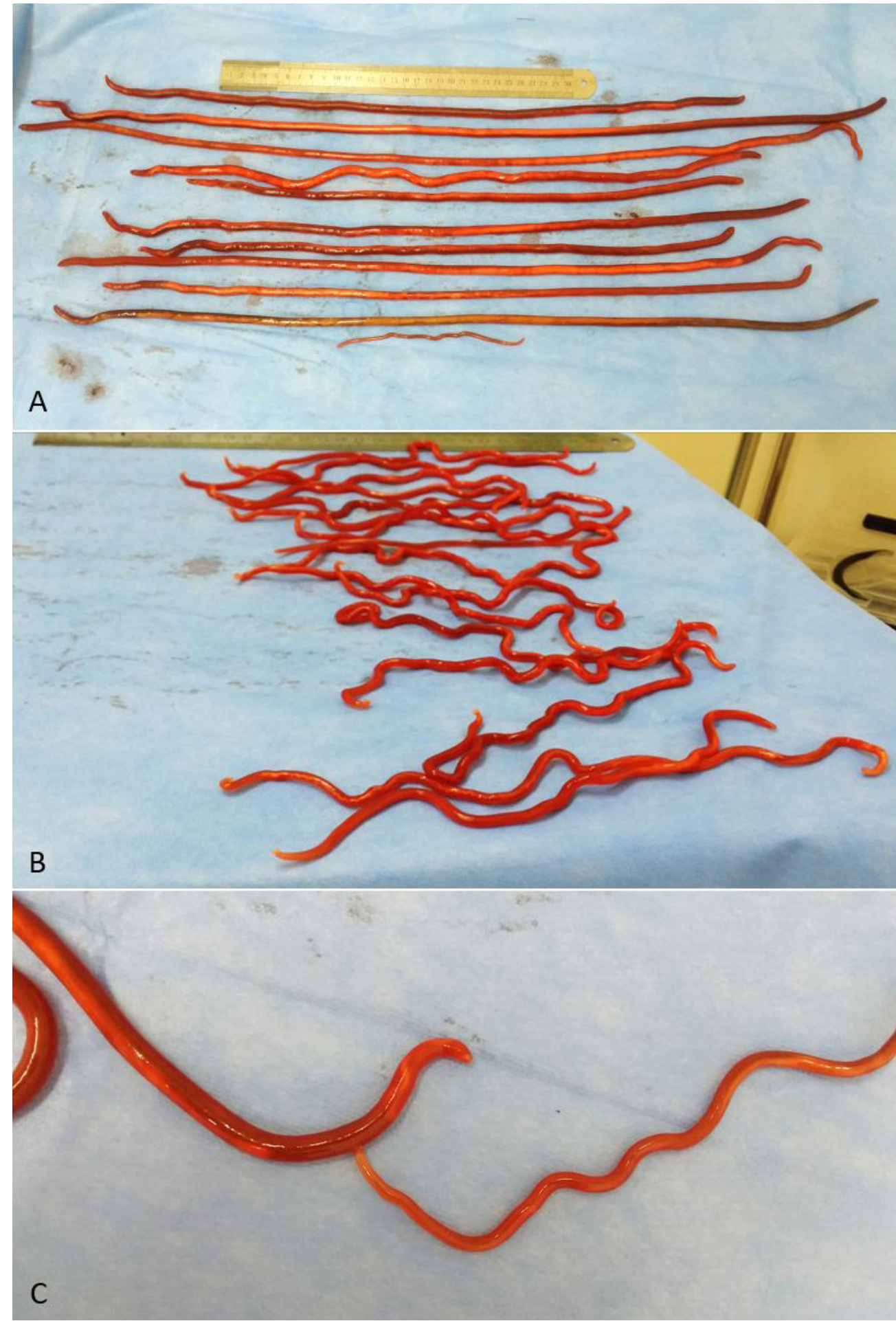

Figure 2. Free parasites removed from the abdominal cavity of a dog. (A) Females; (B) Males; (C) Copulation between two parasites, with the male united with the female by means of the copulatory bursa. The length of the ruler is $30 \mathrm{~cm}$. The parasites presented motility, shown by the curvature of their bodies. 
Samples were collected from the surface of each parasite using a sterile swab. These samples were sent for bacterial culturing in blood agar and MacConkey agar, and there was no growth of microbes in either of these. Histopathological analysis on fragments from the omentum revealed the presence of intense inflammatory infiltrate of lymphocytes, plasmacytes and macrophages. Very many eggs of $D$. renale, of rugose and bioperculate appearance, were found in the middle of the inflammatory connective tissue (Figure 3).

There have been reports of similar cases of multiparasitism caused by $D$. renale. In reports on dogs examined through necropsy, Monteiro et al. (2002) found 34 parasites (28 in the abdominal cavity and six in the right kidney) and Sadighian \& Amini (1967) found 27 adult worms (14 in the right kidney, 10 in the peritoneal cavity and three in the peritoneum). Perera et al. (2017b) reported an in vivo finding of 23 parasites in the abdominal cavity in a single dog, which survived after removal of the nematodes.

The measurements of the 27 parasites described by Sadighian \& Amini (1967) ranged from 29 to $75 \mathrm{~cm}$ among the females and from 21 to $33 \mathrm{~cm}$ among the males. Those sizes were similar to what was found in the present report, which shows that the high parasite load did not interfere with the development of the specimens encountered. In another report in the literature, it is stated that females can reach a length of $100 \mathrm{~cm}$ and males, $45 \mathrm{~cm}$ (Pedrassani \& Nascimento, 2015).

The patient that was followed up in the present report had undergone a cesarean procedure, together with ovariohysterectomy, five months before receiving the diagnosis of dioctophymosis, performed by another professional. There were no reports of any macroscopic alterations seen during those procedures. Therefore, it can be suggested that the disease developed over that five-month period, since the prepatent period of $D$. renale in dogs is estimated to be 135 days (Mace \& Anderson, 1975).

This dog was living in the rural zone of the municipality of Pelotas, in the south of the state of Rio Grande do Sul, Brazil. There have been several cases of animals parasitized by $D$. renale in the Pelotas region (Rappeti et al., 2017). Eggs of this parasite were found in soil samples from the urban region of the city (Perera et al., 2017a), and

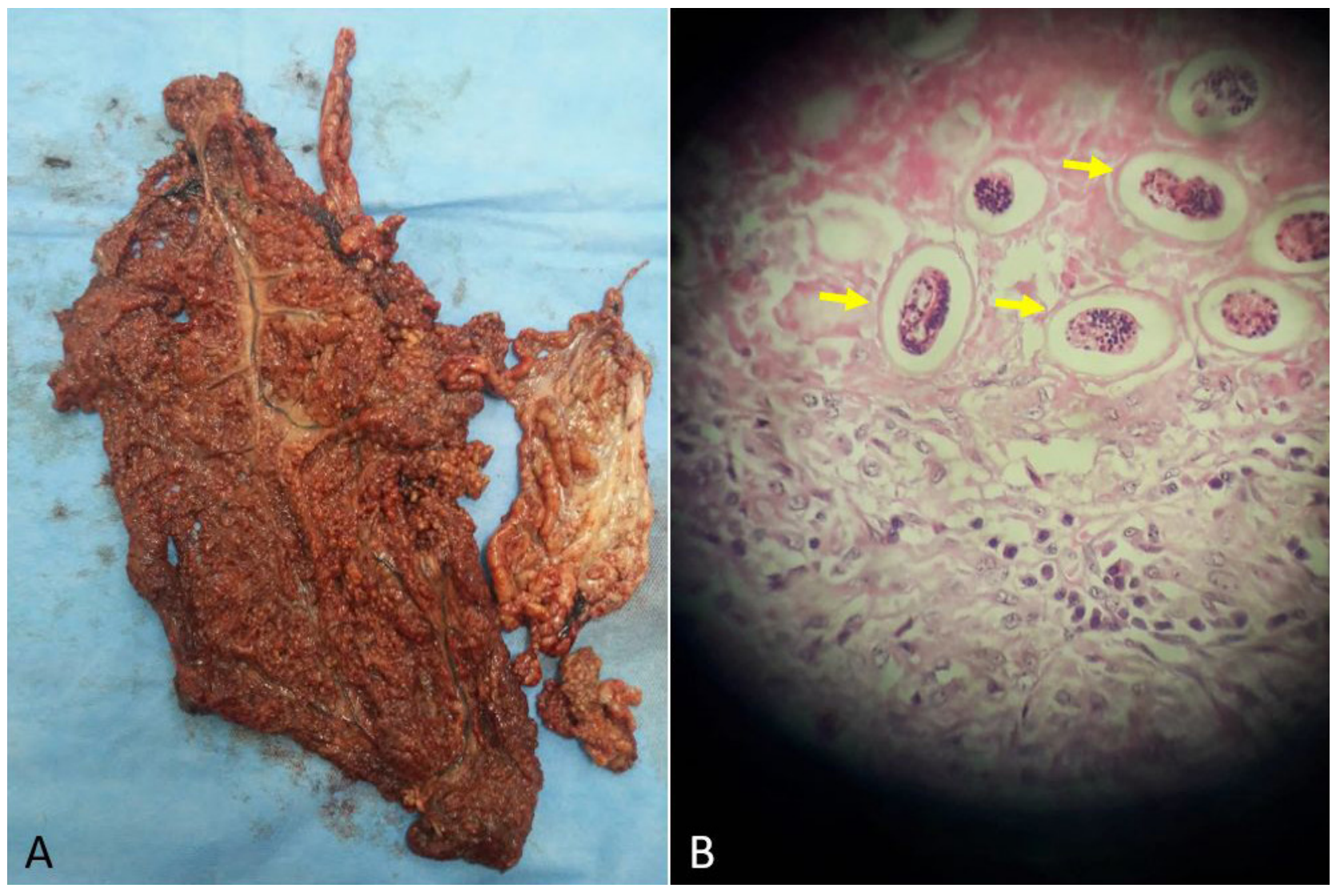

Figure 3. Omentum of a dog with dioctophymosis caused by 34 specimens of Dioctophyme renale. (A) Macroscopic appearance, with intense proliferative reaction and alteration of the tissue coloration and consistency; (B) Microscopic appearance, with intense inflammatory infiltrate consisting of lymphocytes, plasmacytes and macrophages (H\&E; 10x). Arrows: Eggs of Dioctophyme renale surrounded by connective tissue. 
third-stage larvae were found in 50\% ( $n=60)$ of the specimens of the turtle D'Orbigny's slider (Trachemys dorbigni) that were evaluated (Mascarenhas \& Müller, 2015). These surveys show that dioctophymosis is present and disseminated in Pelotas, thus favoring infection with large numbers of worms.

In the report by Monteiro et al. (2002), renal perforation was also found, which allowed passage of parasites. It can be suggested that the high parasite load inside the kidney may have led to dispersal of parasites out from the kidney to the abdominal cavity, given the limited physical space inside the kidney capsule. In addition, there is the possibility that the free worms in the abdominal cavity had perforated the kidney, given that there is a migratory tendency towards this organ (Hallberg, 1953; Mace \& Anderson, 1975). Likewise, considering the anatomical characteristics of the host, migration of the parasites to the right kidney explains the finding that all specimens were observed to be in the right lateral region of the abdomen.

The absence of bacterial growth in the cultures that were performed demonstrated that the parasitosis was not accompanied by bacteria infection. Aseptic peritonitis occurred through mechanical factors, due to the high parasite load and the presence of eggs that had not been eliminated and were causing inflammation and irritation to the tissue (Anderson, 2000). Moreover, chemical factors are also involved, given that the parasites eliminate lipolytic and proteolytic esophageal enzymes, thus causing tissue lysis (Pedrassani \& Nascimento, 2015). The tissue lesions explain the formation of connective tissue and the inflammatory reaction surrounding the eggs, as described by Measures \& Anderson (1985).

We believe that this report presents the largest number of specimens of $D$. renale that have so far been removed from a single dog in vivo (34 specimens). We were unable to find any similar report in the current literature available through the main databases. It was noted that the high parasite load did not impede full development of the parasites, which had reached sexual maturity with elimination of eggs. This led to consequent peritonitis, abdominal inflammatory reaction and tissue destruction.

The patient was still in a clinical stable condition at the time of writing this report, 148 days after the surgical treatment. The creatinine levels remained stable on days 11, 14 and 36 post-surgery, with values of 1.4 mg.dL-1, $1.3 \mathrm{mg} \cdot \mathrm{dL}^{-1}$ and $1.2 \mathrm{mg} \cdot \mathrm{dL}^{-1}$. The urea concentrations progressively decreased $\left(86.65 \mathrm{mg} \cdot \mathrm{dL}^{-1}, 71.93 \mathrm{mg} \cdot \mathrm{dL}^{-1}\right.$ and $64.53 \mathrm{mg} . \mathrm{dL}^{-1}$ ) over these timepoints. Currently, the creatinine concentration is $1.9 \mathrm{mg} . \mathrm{dL}^{-1}$ and urea $97.0 \mathrm{mg} . \mathrm{dL}^{-1}$. The patient continues to be clinically monitored.

\section{References}

Anderson RC. Nematode parasites of vertebrates - Their development and transmission. 2nd ed. New York: CAB International; 2000. http://dx.doi.org/10.1079/9780851994215.0000.

Butti MJ, Gamboa MI, Terminiello J, Radman NE. Dioctofimosis en un canino de 3 meses de edad: reporte de caso. Rev $\operatorname{Arg}$ Parasitol 2018; 7: 33-36.

Butti MJ, Gamboa MI, Terminiello J, Urbiztondo M, Polizzi C, Acosta C, et al. Dioctofimosis renal, abdominal e intraprostática en un canino. Rev Arg Parasitol 2020; 9(1): 27-30.

Caye P, Milech V, Lima CS, Braga FVA, Cleff MB, Rappeti JCS, et al. Intramuscular Dioctophyme renale surgically removed from dog - rare case report. Sch J Agric Vet Sci 2018; 5(5): 266-269.

Hallberg CW. Dioctophyma renale (Goeze, 1782) a study of the migration routes to the kidneys of mammals and resultant pathology. Trans Am Microsc Soc 1953; 72(4): 351-363. http://dx.doi.org/10.2307/3223483.

Mace TF, Anderson RC. Development of the giant kidney worm, Dioctophyma renale (Goeze, 1782) (Nematoda: dioctophymatoidea). Can J Zool 1975; 53(11): 1552-1568. http://dx.doi.org/10.1139/z75-190. PMid:127653.

Mascarenhas CS, Müller G. Third-stage larvae of the enoplid nematode Dioctophyme renale (Goeze, 1782) in the freshwater turtle Trachemys dorbigni from Southern Brazil. J Helminthol 2015; 89(5): 630-635. http://dx.doi.org/10.1017/S0022149X14000364. PMid:24830883.

Measures L, Anderson RC. Centrarchid fish as paratenic hosts of the giant kidney worm, Dioctophyma renale (Goeze, 1782), in Ontario, Canada.J Wildl Dis 1985; 21(1): 11-19. http://dx.doi.org/10.7589/0090-3558-21.1.11. PMid:3157009.

Measures LN. Dioctophymatosis. In: Samuel WM, Pybus MJ, Kocan AA. Parasitic diseases of wild mammals. 2nd ed. Ames: Iowa State University Press; 2001. p. 357-364. http://dx.doi.org/10.1002/9780470377000.ch13.

Mesquita LR, Rahal SC, Faria LG, Takahira RK, Rocha NS, Mamprim MJ, et al. Pre- and post-operative evaluations of eight dogs following right nephrectomy due to Dioctophyma renale. Vet Q 2014; 34(3): 167-171. http://dx.doi.org/10.1080/01652176.2014. 924166. PMid:24832362. 
Monteiro SG, Sallis ESV, Stainki DR. Infecção natural por trinta e quatro helmintos da espécie Dioctophyma renale (Goeze, 1782) em um cão. Rev FZVA 2002; 9(1): 95-99.

Paras KL, Miller L, Verocai GG. Ectopic infection by Dioctophyme renale in a dog from Georgia, USA, and a review of cases of ectopic dioctophymosis in companion animals in the Americas. Vet Parasitol Reg Stud Rep 2018; 14: 111-116. http://dx.doi.org/10.1016/j. vprsr.2018.09.008. PMid:31014715.

Pedrassani D, Nascimento AA, André MR, Machado RZ. Dioctophyme renale: prevalence and risk factors of parasitism in dogs of São Cristóvão district, Três Barras county, Santa Catarina State, Brazil. Rev Bras Parasito/ Vet 2017; 26(1): 39-46. http://dx.doi. org/10.1590/s1984-29612017004. PMid:28198911.

Pedrassani D, Nascimento AA. Verme gigante renal. Rev Port Ciênc Vet 2015; 110(593-594): 30-37.

Perera SC, Capella GA, Pinto NB, Rappeti JCS, Müller G, Azambuja RHM, et al. First isolation of Dioctophyme renale eggs from an urban environment and identification of those from animal urine. Rev Bras Parasitol Vet 2017a; 26(1): 89-91. http://dx.doi. org/10.1590/s1984-29612016064. PMid:27925059.

Perera SC, Rappeti JCS, Milech V, Braga FA, Cavalcanti GAO, Nakasu CC, et al. Eliminação de Dioctophyme renale pela urina em canino com dioctofimatose em rim esquerdo e cavidade abdominal - Primeiro relato no Rio Grande do Sul. Arq Bras Med Vet Zootec 2017b; 69(3): 618-622. http://dx.doi.org/10.1590/1678-4162-9036.

Radman NE, Gamboa MI, Butti MJ, Blanco M, Rube A, Terminiello J, et al. Occurrence of dioctophymatosis in canines within a riparian zone of the Río de la Plata watercourse, in Ensenada, Buenos Aires Province, Argentina. Vet Parasitol Reg Stud Rep 2017; 10: 43-50. http://dx.doi.org/10.1016/j.vprsr.2017.07.007. PMid:31014597.

Rappeti JCS, Mascarenhas CS, Perera SC, Müller G, Grecco FB, Silva LMC, et al. Dioctophyme renale (Nematoda: Enoplida) in domestic dogs and cats in the extreme south of Brazil. Rev Bras Parasito/ Vet 2017; 26(1): 119-121. http://dx.doi.org/10.1590/ s1984-29612016072. PMid:27925066.

Sadighian A, Amini F. Dioctophyma renale (Goeze, 1782) Stiles, 1901, in stray dogs and jackals in Shahsavar Area, Caspian Region. Iran J Parasitol 1967; 53(5): 961. http://dx.doi.org/10.2307/3276817. PMid:4228861. 